\title{
Pathways for retaining human capital in academic departments of a South African university
}

\begin{tabular}{|c|c|}
\hline \multicolumn{2}{|c|}{$\begin{array}{l}\text { Authors: } \\
\text { Luyanda Dube }{ }^{1} \\
\text { Patrick Ngulube }^{2}\end{array}$} \\
\hline \multicolumn{2}{|c|}{$\begin{array}{l}\text { Affiliations: } \\
{ }^{1} \text { Department of Information } \\
\text { Science, University of South } \\
\text { Africa, South Africa }\end{array}$} \\
\hline \multicolumn{2}{|c|}{$\begin{array}{l}{ }^{2} \text { Department of } \\
\text { Interdisciplinary Research } \\
\text { and Postgraduate Studies, } \\
\text { University of South Africa, } \\
\text { South Africa }\end{array}$} \\
\hline \multicolumn{2}{|c|}{$\begin{array}{l}\text { Correspondence to: } \\
\text { Patrick Ngulube }\end{array}$} \\
\hline \multicolumn{2}{|c|}{$\begin{array}{l}\text { Email: } \\
\text { ngulup@unisa.ac.za }\end{array}$} \\
\hline \multicolumn{2}{|c|}{$\begin{array}{l}\text { Postal address: } \\
\text { PO Box 392, Pretoria 0003, } \\
\text { South Africa }\end{array}$} \\
\hline \multicolumn{2}{|c|}{$\begin{array}{l}\text { Dates: } \\
\text { Received: } 19 \text { Feb. } 2013 \\
\text { Accepted: } 24 \text { June } 2013 \\
\text { Published: } 29 \text { July } 2013\end{array}$} \\
\hline \multicolumn{2}{|c|}{$\begin{array}{l}\text { How to cite this article: } \\
\text { Dube, L. \& Ngulube, P., 2013, } \\
\text { 'Pathways for retaining } \\
\text { human capital in academic } \\
\text { departments of a South } \\
\text { African university', SA Journal } \\
\text { of Information Management } \\
\text { 15(2), Art. \#560, } 8 \text { pages. } \\
\text { http://dx.doi.org/10.4102/ } \\
\text { sajim.v15i2.560 }\end{array}$} \\
\hline \multicolumn{2}{|c|}{$\begin{array}{l}\text { Copyright: } \\
\text { (C) 2013. The Authors. } \\
\text { Licensee: AOSIS } \\
\text { OpenJournals. This w } \\
\text { is licensed under the } \\
\text { Creative Commons } \\
\text { Attribution License. }\end{array}$} \\
\hline \multicolumn{2}{|l|}{ Read online: } \\
\hline arifn & $\begin{array}{l}\text { Scan this QR } \\
\text { code with your } \\
\text { smart phone or } \\
\text { mobile device } \\
\text { to read online. }\end{array}$ \\
\hline
\end{tabular}

Background: The article underscores the process of knowledge retention for academics in select academic departments in the College of Human Sciences (CHS) at the University of South Africa (UNISA). The knowledge economy is ubiquitous and necessitates that organisations foster innovation and improve efficiency, effectiveness, competitiveness and productivity through knowledge retention. In an academic setting, which is the focus of this article, the situation is no different because there seems to be an accord worldwide that the quality of higher education largely depends on the qualifications of staff and professorial capability in quality research, instruction and doctoral level certification. By implication, it is critical that the retention of knowledge should be prioritised to ensure the curtailment of the impact of knowledge attrition.

Objective: The study intends to profile knowledge assets in CHS, determine retention strategies and offer suggestions about regenerating knowledge retention initiatives.

Research methodology: A quantitative approach, more specifically the informetrics technique of data mining, was adopted to profile academics in CHS at UNISA.

Results: The results confirm the assertion that there is a discrepancy between senior academics who are probably due to leave the university in the next few years, and entrants who will replace them. The issue is worsened by the lack of an institutional framework to guide, standardise, strengthen or prioritise the process of knowledge retention.

Conclusion: The study recommends the prioritisation, formalisation and institutionalisation of knowledge retention through the implementation of a broad range of knowledge retention strategies.

\section{Introduction}

Literature has revealed that in the knowledge-driven economy, knowledge is regarded as a strategic, valuable and competitive asset that enables organisations to foster innovation and improve efficiency, effectiveness, productivity and competitiveness (Alstete 2003; Desouza \& Awazu 2004; Drucker 2001; Hira 2011; Horwitz, Heng \& Quazi 2003). This is based on the notion that knowledge is deemed to be central not only to power, but also to wealth. Knowledge is embodied in a person or carried, created, augmented, improved, applied, taught and passed on, used or misused by a person; which means that the person is at the centre (Castro 2008; Choo \& Bontis 2002; Drucker 2001; Nelson \& McCann 2010). Unlike during the industrial age where physicality was of primary importance, in the knowledge economy it is the brains rather than the brawn of the workforce that will add value to intelligent organisations or learning organisations (Alvin Toffler, cited in Desouza \& Awazu 2004). Thus, it is knowledge, the intellectual capital of astute workers, which is the fundamental resource for economic development.

The inherent value of knowledge means that the leverage of knowledge assets is imperative. Obviously, if those who possess this powerful resource leave the organisation, they take away the knowledge, skills and experience accumulated over a period of years on the job (Hira 2011; Horwitz et al. 2003; Knoco Ltd n.d.; Madsen, Mosakowski \& Zahher 2003; Malthora 2003; Ramlall 2003; Smith 2007; Tettey 2006). Clearly, knowledge attrition encompasses loss of skills, experience, knowledge, corporate memory and, more importantly, the loss of strategic competitive advantage (Castro 2008; Choo \& Bontis 2002; Drucker 2001; Nelson \& McCann 2010; Smith 2007). Thus, if critical knowledge is not retained, organisations will have to continually reinvent the wheel. As indicated in the literature, this will result in wastage of resources, which organisations cannot afford in this era of economic turmoil and global competition. Given the value of knowledge, organisations undoubtedly need to have strategies to capture, retain and manage knowledge before it is lost.

Needless to say, knowledge retention is critical to organisational success, but not all knowledge in an organisation is worth retaining. Knowledge that warrants retention is that which is valuable 
in terms of affording competitive advantage due to its rarity, relevance, heterogeneity or non-substitutability (Ramlall 2003; Smith 2007; Tettey 2006). It is critical knowledge, often embodied in experience, skills, knowledge and capabilities of individuals and groups, that is worth retaining (Seidman \& McCauley, cited in Martins 2010). These individuals are employees with exceptional capabilities that are critical for the development of organisational competence (Castro 2008; Choo \& Bontis 2002). Such employees have a high degree of expertise, education or experience in the execution of their jobs (Davenport \& Prusak 2000; Hira 2011). Drucker (2001) refers to these employees as 'knowledge workers' or 'golden workers'. Clearly, the tacit knowledge possessed by these individuals is invaluable and irreplaceable; hence, it should be retained to avoid knowledge gaps that will have a strategic impact on the achievement of organisational goals (Castro 2008; Choo \& Bontis 2002).

Knowledge retention is a multifaceted component of an organisation's human resource strategies to retain expert and critical knowledge (Frank, Finnegan \& Taylor 2004; Martins 2010). Knowledge retention begins with the hiring of people with the right skill sets, mindsets and experience; it also entails the deliberate and persistent retention of these employees so that competitors cannot get hold of them (Castro 2008; Choo \& Bontis 2002; Frank et al. 2004). Embedded in knowledge retention is the identification of risks that could lead to knowledge loss (Nelson \& McCann 2010; Ramlall 2003; Smith 2007; Tettey 2006, 2010). As indicated in the literature, knowledge retention is also a cost-cutting strategy, considering that knowledge is a valuable asset that has to be managed strategically to maintain competitive advantage (Madsen et al. 2003; Malthora 2003; Nelson \& McCann 2010; Tettey 2006, 2010).

Due to recent trends in the world of work, knowledge retention has been lauded as a useful strategy to mitigate turnover challenges that threaten organisational survival and growth. The latest trends include 'war for talent' (Axelrod, Handfield-Jones \& Welsh, cited in Oosthuizen \& Nieber 2010), which is based on the heightened appreciation for the value of knowledge and increased mobility of employees with critical knowledge as they are hunted by many organisations (Lom 2012; MacGregor 2008; Martins 2010; Thomas 2009; Wamundila \& Ngulube 2011). It is imperative for organisations to face this reality as it threatens stability and growth. Thus, it becomes critical that organisations should manage turnover challenges deliberately and purposefully through appropriate retention strategies that are capable of strengthening intellectual capital renewal and mitigating knowledge attrition or 'organisational forgetting' (Castro 2008; DeLong 2004; Malthora 2003; Nelson \& McCann 2010). Therefore, organisations need to figure out beforehand which knowledge, if lost, could undermine the organisational strategy (DeLong 2004) and whose knowledge might be at risk of being lost (Martins 2010). This is critical because there is evidence according to Castro (2008), Choo and Bontis (2002) and DeLong (2004) that organisations cannot compete effectively in the knowledge economy unless they are serious about knowledge retention.

\section{Knowledge retention in academe: Challenges and prospects}

Badat (2010) affirms that the South African academic workforce exhibits complexity because it was racialised and gendered, which bestowed South African universities with a predominantly White male academic workforce. In the first decade since democracy (1994-2004) most professors and associate professors in South African universities, who constitute most highly qualified, experienced and productive researchers and are experts in their chosen disciplines, are older workers above the age of 50. Unfortunately, as observed by Badat (2010) and Van der Walt (2010), the trend seems to be ongoing. For instance, there is evidence that even after 2004 the most highly qualified, experienced and top-rated researchers are largely White, older men, although in the past few years there has been a slow progression of African scholars entering the professoriate bracket.

Some of the pronouncements that were linked to the transformation of the higher education landscape had adverse effects for the retention of academic human capital. After 1994 the retirement age for academic employees was reduced by most South African universities from 65 to 60 . In view of skewed representation of human capital in academe as presented in the foregoing arguments, it is disheartening to note that on the basis of the current retirement age most senior academics are due to retire in the next five to ten years. As a form of intervention, the Minister of Higher Education articulated that it was counter-productive to let university professors and lecturers retire at 60, when they could still help train desperately needed skilled professionals. In response to the situation, most universities reverted back to 65 as the retirement age for academic employees.

Action to retain knowledge in academe is needed if universities are to serve humanity in the wake of an ageing workforce. For instance, Professor Saleem Badat, vice-chancellor of Rhodes University, warned that '[w]ithout action, South Africa's efforts to transform the social composition of its scholarly workforce will be undermined, academic quality will be debilitated along with the capacity to produce high quality graduates and knowledge, and their ability of universities to contribute to development and democracy through a new generation of outstanding scholars committed to critical and independent scholarship and social justice will be hampered'. In the case of Senegal, Lom (2012) observed that Senegal's premier Université Cheikh Anta Diop (UCAD) in Dakar was set to lose $60 \%$ to $70 \%$ of academics by 2015 as a result of large-scale retirements.

It is undeniable that senior academics fit into the category of golden workers. This is because they bear the responsibility that entails increasing the research output by not only supervising postgraduate students but also publishing in accredited journals. Supervision and publishing are both critical elements that determine the ranking of the institution as well as its standing and visibility in the national and international academic milieu. Needless to say, several factors 
contribute to the ranking process, which is multifaceted and complex. However, what cannot be denied is the importance of the right skill levels, unique capabilities, knowledge and experience that can only be acquired over time. This highlights a challenge wherein experienced academics will be exiting the system without an equivalent entry rate by young researchers. This discrepancy creates a void or imbalance in scholarly and academic productivity and growth.

However, the fact of the matter is that it is not only through the retirement conduit that knowledge assets are lost. There other suppositions or causal factors that lead to the growing number of senior academics retiring and exiting the workforce and the shrinking pool of qualified younger academics. These include such risk factors as staff turnover (resignations), downsising, retrenchment, emigration, employment equity, mergers, acquisitions, globalisation, uncompetitive remuneration packages, onerous working conditions and the notion of advancing equity versus realising academic excellence (Habib \& Morrow 2006; Lom 2012; MacGregor 2008; Martins 2010; Notshulwana 2011; Tettey 2006, 2010; Wamundila \& Ngulube 2011). It becomes very clear in the literature that South African academics are inadequately remunerated relative to occupations in the public sector (state, public enterprises and science councils) and private sector that require similar levels of qualifications and expertise. To the detriment of universities, the economy and society at large, the remuneration differences between universities and the public and private sectors also discourages potential academics (postgraduate students) to replace at an equivalent pace the void that will be left by the exiting professoriate (Habib \& Morrow 2006; Notshulwana 2011).

Clearly, these differences cause academics to be relatively mobile and to be continuously drawn to administrative portfolios and management positions within universities; some focus on commissioned research, some divert to consultancy work and some move to the public and private sectors. Unfortunately, as Ntuli (2007) cautions, job hopping usually exerts pressure on organisations' stability and sustainability. The costs of replacing employees refer to separation or severance pay, recruiting replacements, developing their skills and experience and factoring in a loss of productivity (Ntuli 2007).

It is worth noting that universities generally face challenges from different fronts that impact negatively or positively on their financial standing, which has a direct impact on academic excellence. For instance, challenges that universities are likely to face include (but are not limited to) competition for students, financial constraints, political interference, academic credibility, low throughput rates, low research output, meeting institutional, local, national and international imperatives and market expectations. As one can deduce, most of these are worsened by the lack of intellectual capital and academic capabilities that are critical competencies for academic and research excellence, innovation and leadership.
As indicated earlier, it is undisputed that the greatest deterrence to knowledge attrition is a robust knowledge management initiative that will enable existing information to circulate efficiently, thereby reducing the impact of attrition on organisational knowledge. In view of the preceding statement, the problem facing academe is how to retain knowledge vital to academic success, efficiency and sustainability whilst also mitigating the decline of the country's scholarly profile and infrastructure in the coming decades.

Establishing a strategy to cope with knowledge attrition may save academic institutions millions, if not billions, of rands every year. It is critical that universities should save money whenever possible to ensure sustainability in an era characterised by national and global economic volatility. It is clear that knowledge retention strategies may enable organisations to manage critical intellectual assets by determining risk and thereby creating a provision whereby the exiting of experienced scholars and the entry of new scholars are systematically balanced with each other. Through knowledge retention strategies, critical knowledge may be transferred to new entrants to ensure that they establish and develop confidence and academic credibility in academic circles. The value of this initiative is multifaceted: it will contribute to personal and professional growth but, of more importance, it will also contribute to organisation effectiveness, efficiency, growth, sustainability, resilience and competitive advantage.

\section{Research questions}

It is an undisputed fact that employee turnover is a considerable university problem. Knowledge management, with its focus on retaining and transferring knowledge, holds the promise of solutions to resolve the problem of knowledge attrition. The critical question posed by Alstete (2003) and Desouza and Awazu (2004) is that in the knowledge economy do universities have a rudimentary understanding of the necessity and imperative to retain tacit knowledge? Based on this notion, this article intends to give a profile of knowledge assets and identify retention practices and strategies that are in place in the College of Human Sciences (CHS) at the University of South Africa (UNISA). The following are the research questions that informed this study:

- What is the nature and range in terms of intergeneration and interracial actualities of knowledge assets in the College of Human Sciences?

- What strategies does the College of Human Sciences use to retain knowledge assets?

- How can the College regenerate knowledge retention initiatives?

\section{Research methodology}

The study adopted a quantitative approach, more specifically the informetrics technique of data mining, to profile academics in CHS at UNISA. This study employed data mining techniques as outlined in Onyancha (2010) to extract data from the Institutional Information and Analysis Portal 
maintained by the Department of Information and Strategic Analysis (DISA) at UNISA. The Department of Information and Strategic Analysis uses Higher Education Data Analyzer (HEDA) software to provide automated, accurate and up-todate web-based information. The study is based on 2011 data. The study utilised an analytical and descriptive method to present the data from the institutional management system as well as related documents.

\section{Findings}

This section presents and discusses the findings of the study.

\section{Academic staff profile in the College of Human Sciences}

The object of the article was to profile knowledge assets in $\mathrm{CHS}$ according to nature and range by analytically looking at the intergeneration, interracial and gender actualities. As indicated earlier, knowledge assets are designated as the highly qualified, experienced and productive researchers, who are mostly professoriate. These are the people whom the university should target and prioritise as most of them are likely to exit in the next few years. However, providing data on all academic levels, including lower categories, was deemed necessary to give a broader picture of the academic staff profile in CHS. Providing concrete data will build a case for knowledge retention in the college which could necessitate the prioritisation of the retention of critical knowledge. Figure 1 gives a synopsis of the staff profile according to different academic levels or categories.

The structure in Figure 1 shows that the total numbers of permanent academic staff members in CHS is 472 . From this number the highest percentage were at lecturer level (117; $25 \%)$, followed by professors $(111 ; 24 \%)$, associate professors $(90 ; 19 \%)$, senior lecturers $(80 ; 17 \%)$ and lastly junior lecturers (74; 16\%). The implications of this distribution will only be evident when dynamics of age, gender and race are factored in. If, for instance, the average age of the professoriate is, as alleged in the literature, in the bracket above 50, this would be a cause for concern. At this stage it might be reasonable not to pre-empt this issue since it will be interrogated in the sections below.

Table 1 reports the following.

\section{Professors}

Professors constitute the second largest group (111 or $24 \%$ ) after senior lecturers (117). The age distribution in this category is an issue that should concern the college. Considering that the retirement age at UNISA stands at 60 $(14 \%)$ of academics in this category are likely to retire in the next few years, with the exception of those who were in the employ of UNISA before the retirement age was adjusted from 65 to 60 . Notably, there are a number of academics (4\%) who are above the 60 years bracket and who can be accorded the extension of contracts in particular cases. This is

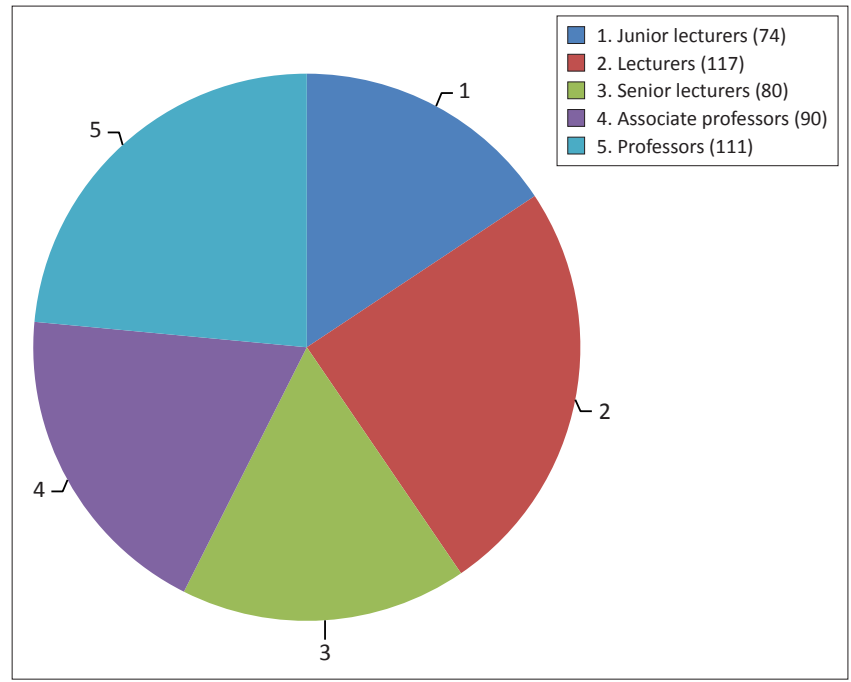

FIGURE 1: Levels or categories of academic staff.

TABLE 1: Profile of academics in the College of Human Sciences.

\begin{tabular}{|c|c|c|}
\hline Category & Age & $\%$ \\
\hline \multirow[t]{4}{*}{ Professors $\dagger$} & $30-39=7$ & 1 \\
\hline & $40-49=20$ & 4 \\
\hline & $50-59=66$ & 14 \\
\hline & $60-69=18$ & 4 \\
\hline Total & 111 & 24 \\
\hline \multirow[t]{4}{*}{ Associate professors: } & $30-39=9$ & 2 \\
\hline & $40-49=31$ & 7 \\
\hline & $50-59=15$ & 3 \\
\hline & $60-69=35$ & 7 \\
\hline Total & 90 & 19 \\
\hline \multirow[t]{4}{*}{ Senior lecturers§ } & $30-39=6$ & 1 \\
\hline & $40-49=21$ & 4 \\
\hline & $50-59=34$ & 7 \\
\hline & $60-69=19$ & 4 \\
\hline Total & 79 & 17 \\
\hline \multirow[t]{5}{*}{ Lecturers and junior lecturers $\Phi$} & $20-29=21$ & 4 \\
\hline & $30-39=55$ & 12 \\
\hline & $40-49=63$ & 13 \\
\hline & $50-59=41$ & 9 \\
\hline & $60-69=11$ & 2 \\
\hline Total & 191 & 40 \\
\hline
\end{tabular}

$\dagger$, youngest and oldest $32 \leq 65$.

t, youngest and oldest $33 \leq 63$.

$\$$, youngest and oldest $33 \leq 63$

Toungest and oldest $24 \leq 64$

a short-term solution; the risk or the threat needs long-lasting solutions to ensure continuity and growth in academic excellence, innovation and leadership.

The reality of the situation is that about $18 \%$ of college staff members, who are mostly renowned scholars and rated researchers (golden workers), are due to retire soon. These are attributes that add value not only to the department but also to the college and the university at large. Only 5\% of college professors are under 50 years old. It is commendable though that only $1 \%$ of academics in the professoriate category are between 30 and 39 years old. Given the regular mobility of academics as discussed previously in this article, the retention of younger academics might be a risk that the college as well as the university would like to consider seriously since it cannot be guaranteed. 


\section{Associate professors}

Associate professors constitute $19 \%$ of the total academics in the college. In this category, the 60-69 age bracket (7\%) poses a threat or a risk to attrition of academic intellectual capital. As indicated earlier these are people who were appointed before the implementation of the new retirement age. Clearly, since there are people over 65 the likelihood is the extension of contractual agreements. Nevertheless, that is a short-term solution as these people will still retire soon. However, it is promising that below the age of 50 there are about $9 \%$ of academics who are likely to be here longer to further the goals of the college and the university.

\section{Senior lecturers}

Senior lecturers are in the middle of the academic ladder, positioned between the professoriate and lower academic levels. Evidently, $11 \%$ of college staff in this category are between the ages of 50 and 69 . This is a cause for concern considering that about $4 \%$ are already beyond the current retirement age. Looking at the two senior levels discussed above, this category is by implication under tremendous pressure to progress and fill in the ranks in the professoriate categories. Although upward mobility may have its challenges, the college and the university might consider implementing strategies to regenerate this group to enhance upward mobility. However, cognisance should be taken of the fact that it is not merely about numbers moving up. In essence it is about academic and scholarly competencies embodied in integrity, professionalism and excellence.

\section{Lecturers and junior lecturers}

Lecturers constitute $25 \%$ and junior lecturers $16 \%$ of academics in CHS. As indicated in Table 1, about $11 \%$ in these categories are between the ages of 50 and 69 . However, a reasonable $29 \%$ of college academics in this category are between the ages of 20 and 49. Related to this is the number of honours or master's graduates who can be attracted to academe by narrowing remuneration differentials between academe and the private and public sectors. This could actually be regarded as an encouraging element for the college, because these are future professors who need to be leveraged, developed and nurtured properly through progressive retention strategies.

\section{Gender differentiation in the college}

It has emerged in the literature that White men dominate the ranks, especially in the category of the professoriate. After 1994 the transformation of the higher education landscape introduced initiatives to redress these imbalances.

The numbers from Figure 2 show that at the number of male professors and associate professors exceeds that of their female counterparts. In the category of professors $67 \%$ are male and 33\% female, and for associate professors 53\% are male and $47 \%$ female. In lower academic categories there are more female than male academics. This translates into the following numbers of female academics in the different categories: senior lecturers 56\%, lecturers $63 \%$ and junior lecturers $62 \%$. Evidently, the gender discrepancy is slightly narrower or marginal at associate professor and senior lecturer levels. Considering the gender representation in academe, the data confirms the assertion mentioned earlier by several authors that men dominate in the ranks of the professoriate and women are still more dominant in lower ranks. Based on institutional imperatives towards gender representation or empowerment, the college might consider strengthening initiatives to advance the cause of female academics. The causes and implications of this matter are beyond the parameters of this study.

\section{Differentiation according to racial ranges}

As indicated earlier the higher education landscape was racialised and politicised. This section presents differentiations according to racial ranges. To summarise, the study confirms the pronouncements made earlier in this article that White academics dominate in numbers in the professoriate. For professors, $76 \%$ are White, $17 \%$ are African, $4 \%$ are Indian and $4 \%$ mixed race. There are $51 \%$ White associate professors, $41 \%$ are African, $4 \%$ are Indian and $3 \%$ are mixed race. For senior lecturers $54 \%$ are African, $44 \%$ are White, $8 \%$ are mixed race and $1 \%$ are Indian. At lecturer and junior lecturer levels 51\% are African, whilst $39 \%$ are White, $5 \%$ Indian and $4 \%$ mixed race. Notably, at professoriate level there is a huge discrepancy between

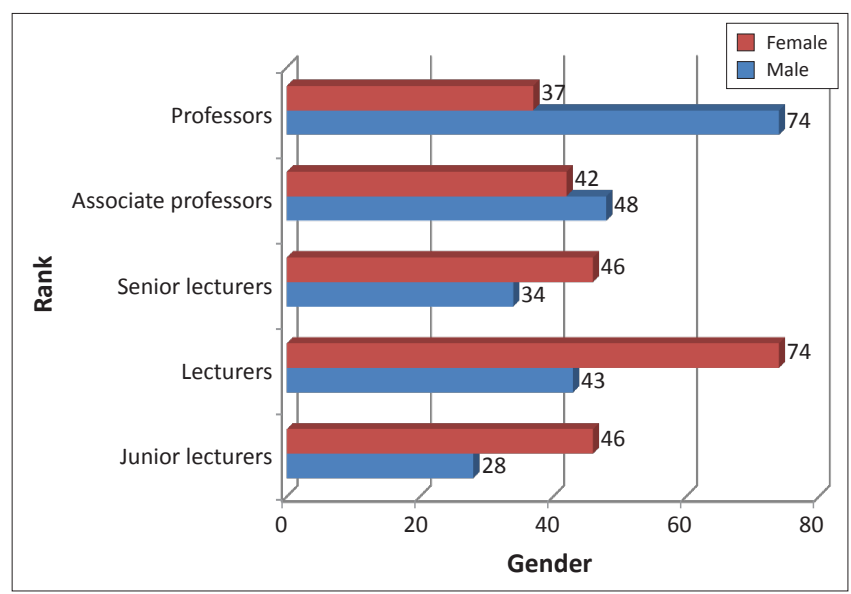

FIGURE 2: Female versus male academics.

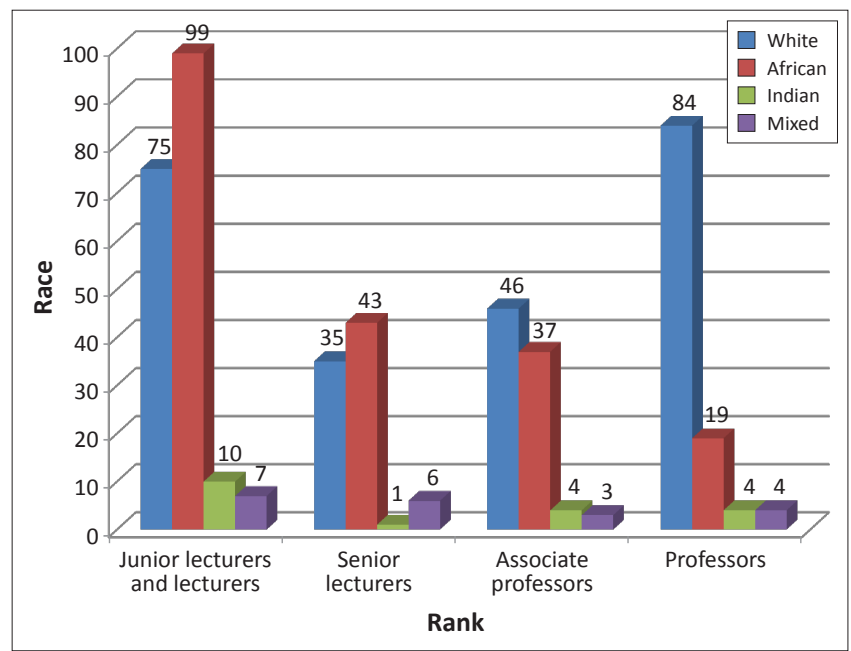

FIGURE 3: The racial differentiation. 
the different racial groups. At associate professor level the discrepancy is marginal between African and White professor and it widens between them and Indian and mixed race professors. At senior lecturer level African lecturers are in the majority, followed by White, mixed race and Indian lecturers. At lecturer and junior lecturer levels African lecturers are in the majority, followed by White, Indian and mixed race lecturers respectively. It should be cautioned that in terms of knowledge retention the racial representation might have negative implications. Several studies reveal that racial ranges or diversity can have negative undertones for knowledge flows and transfer. Given that knowledge retention includes the systematic transference of knowledge from golden workers to other employees, if it is not properly managed to lessen the impact of racial differentiations, it might not succeed irrespective of its noble intentions.

\section{Knowledge retention in the College of Human Sciences: How can it be regenerated?}

Organisations differ from one another in terms of strategic focus, how pressing the nature of the knowledge retention problem is and the fact that there clearly is no 'one-size-fitsall' solution when it comes to knowledge retention (DeLong \& Davenport 2003). Knowledge retention partly involves the transfer and sharing of knowledge, skills and competencies. Studies by Finestone and Snyman (2005) indicate that cultural, racial, ethnic and national differentiations are rampant in South African organisations. These breed a lot of mistrust, resentment, competitiveness and a lack of collective goals. As indicated earlier, for knowledge sharing to flourish, the environment has to be enabling, and other enhancers and possible inhibitors have to be identified and managed to maximise or cancel out their impact. Based on the preceding discourse this section examines knowledge retention strategies in CHS and suggests how these could be regenerated. The strategies presented are distilled from the researchers' experience as academics at UNISA.

\section{Institutional knowledge retention framework}

The University of South Africa does not have a specific knowledge retention policy. Some knowledge retention issues are integrated in various human resource policies such as the Policy for the Integrated Performance Management System (IPMS). This policy is aimed at recruiting, developing and retaining employees with the requisite mindsets, knowledge and skills to achieve the university's Agenda for Transformation (UNISA 2008). The policy generally provides an overview of IPMS-related issues and does not provided succinct information about the management of knowledge assets. Due to the lack of guiding frameworks or canons on knowledge retention the practice remains uncoordinated and haphazard. This results in an institutional culture that does not enhance knowledge sharing. It perpetuates a culture that is still leaning towards recognising and rewarding individual excellence. Without the provision of an enabling culture as well as the alignment of institutional systems and policies, it will be difficult for UNISA as an institution to negate the effects of knowledge attrition. The institution needs a succinct knowledge retention strategy that will be responsive to the institutional needs and culture. A knowledge retention strategy will also enable the institution to retain critical intellectual capital.

\section{Talent management}

As indicated by Wellins, Smith and Erker (2006), organisations need to realise that their financial value often depends upon the quality of the talent. The term talent usually refers to a blend of skills, knowledge, cognitive ability, values and preferences that give individuals the highest levels of potential (Jeffrey 2011). Because there is no universal definition of the term talent, it is important that each organisation should define the term according to local realities. Despite issues with the definition of the term, there is a unanimous sense that talent is a critical resource that organisations should prioritise. Jeffrey (2011) reiterates the fact that due to the economic downturn organisations need to invest in people in order to maximise innovation and the capability to meet challenges of the future. The University of South Africa (UNISA) has a diverse workforce with unique combinations, backgrounds, skills and experience. In order to manage and maximise diversity, it has introduced talent management programmes in the past few years. These programmes, amongst other things, include formalised mentorship programmes. Given the value of knowledge, it is critical that the university harnesses knowledge retention through what Wellins et al. (2006) refer to as the ability to effectively hire, retain, deploy and engage talent for competitive advantage. To be effective, UNISA needs not only to invest in talent management but also to align remuneration and other institutional systems and processes with the crux of talent management. Failure to invest in people (talent) could lead to the loss of critical skills and of the richness of future talent (Jeffrey 2011). Ideally, the decision to invest in the institutional talent has to be preceded by a knowledge audit that will map out knowledge assets at risk as well as gaps in the depth and breadth of organisational knowledge. Clearly, without this exercise the institution will not have a clear picture of the nature and extent of knowledge threats and gaps.

\section{Mentorship programmes}

In the College of Humanities, senior academics are expected to mentor young academics and those on probation. The object of these mentorship programmes is to familiarise new entrants with the systems, processes and practices of UNISA as an open distance learning (ODL) institution. Mentorship programmes are still in their infancy; one can deduce that they are still piloted as there no clear guidelines informing them. From the foregoing arguments it can be deduced that the existing mentorship programmes might not be adequate for knowledge retention due to their intention, focus and time span, the pairing of mentors and mentees and the lack of monitoring mechanisms and a guiding framework. To enhance knowledge retention through mentorship programmes UNISA needs to have a clear regulatory framework with clear guidelines, targets and evaluation mechanisms. 


\section{Career conversations}

In the college, there are career conversations between academics to a limited extent. These are in the form of workshops, meetings, seminars and conferences. These career conversations are usually at departmental, interdepartmental, institutional and inter-institutional levels. If these could be deepened and purposefully driven by leveraging knowledge assets, they might maximise the transfer and retention of critical academic knowledge, skills and competencies. In line with the university prescripts, career conversations could lead to collaborative projects and initiatives.

\section{Exit interviews}

It is the norm at UNISA, as in many other organisations, that when employees leave they partake in an exit interview. Once again these interviews are not driven by knowledge retention goals. They are more focused on identifying causal factors for high turnover, which may be useful for determining turnover trends. For knowledge retention purposes, exit interviews need to ensure that critical tacit knowledge is leveraged, harvested and retained through personification or codification approaches. Ideally, institutions should not wait until knowledge assets threaten to leave or exit. Instead of being reactive, institutions should be proactive through human resources and other appropriate strategies. These include purposeful recruitment and hiring based on identified risks and threats that are likely to impact on critical knowledge assets. If the process is strategically and deliberately managed, institutions can avert knowledge attrition and maintain competitive advantage.

\section{Career development}

The university champions the provision of opportunities for personal as well as professional development. Comparatively speaking, UNISA as an institution has progressive and fair opportunities for growth and upward mobility. For instance, there are deliberate and conscious efforts to empower those who were previously marginalised, through skills development funding, ad hominem promotions, research awards, National Research Funding grants, support for conference, workshop or seminar attendance, leave opportunities, salary adjustments based on performance management systems, and many others forms of recognition. Despite these provisions, it is evident that upward mobility for academics is still fairly limited. Mostly, previously disadvantaged people, that is, Black people and women, are confined to the lower academic categories: senior lecturer, lecturer and junior lecturer. Quite evident is the fact is that there is a bottleneck that impedes passage on the trajectory between lectureship and professorship. Given that UNISA provides an open trajectory for upward mobility, there is a need to determine why racial and gender discrepancies are still rampant in the academic profile. Further studies could determine causal factors obstructing academic upward mobility in CHS. Without concrete evidence of the causal factors one can only speculate about what challenges potential candidates face. For example, promotion to professorship is based on research output. This might be a challenge due to a myriad of factors, including:
1. The heavy teaching loads for those in lower level categories compared to higher categories.

2. The lack of research skills resulting from a system of education that did not enhance a strong research ethos or champion the inculcation of research. For example, in most universities research is not embedded in the undergraduate or even postgraduate curriculum. A master's degree by coursework is a case in point.

3. The effects of socialisation wherein most previously marginalised people have not broken the mould to step into the arena of academic scholarship.

4. The consequences of individual as opposed to collective performance. Currently, the reward system is aligned towards individual excellence. Although there is a drive towards developmental or collective initiatives, this has not been factored into reward institutional systems.

\section{Conclusions and recommendations}

The University of South Africa runs the risk of letting knowledge walk out of its door as $14 \%$ of the academics at professorship level may retire in the next few years and $18 \%$ of other college staff members, who are mostly renowned scholars and top-rated researchers, are due to retire soon. Most of them are White men. Strategies to capture and retain their knowledge should be formulated so that it is passed to academics in all categories and both gender groups. In conclusion, there are many uncoordinated initiatives that need to be streamlined and enhanced before knowledge retention is a reality in the institution. In order to manage talent, the university needs to audit its knowledge assets, identify risk areas and put plans in place to mitigate those risks. It needs to align institutional systems and policies with collective performance principles rather than individual performance. Finally, there is a need for the development of an institutional knowledge retention framework that will facilitate the implementation of talent management and mentorship programmes, career conversations, career development initiatives and exit interviews as formal and effective strategies to engender the retention of human capital in the College of Humanities at UNISA.

\section{Acknowledgements Competing interest}

The authors declare that they have no financial or personal relationship(s) that may have inappropriately influenced them in writing this article.

\section{Authors' contributions}

L.D. (University of South Africa) and P.N (University of South Africa) made equal contributions to the writing of this article.

\section{References}

Alstete, J., 2003, Trends on corporate knowledge asset protection, viewed 17 February 2011, from http://www.tlainc.com/articl147.htm

Badat, S., 2010, The challenges of transformation in higher education and training institutions in South Africa, viewed 11 February 2011, from http://www.dbsa. org/pdf 
Castro, M.L., 2008, 'The relationship between organisational climate and employee satisfaction in a South African information and technology organisation', MA dissertation, Department of Psychology, University of South Africa.

Choo, C.W. \& Bontis, N., 2002, 'Knowledge, intellectual capital, and strategy: Themes and tensions', in C.W Choo \& N. Bontis (eds.), The strategic management of intellectual capital and organizational knowledge, pp. 3-22, Oxford University Press, Oxford.

Davenport, T.H. \& Prusak, L., 2000, Working knowledge: How organizations manage what they know, Harvard Business School Press, Boston

DeLong, D.W., 2004, Lost knowledge: Confronting the threat of an aging workforce, Oxford University Press, Oxford. http://dx.doi.org/10.1093/acprof:oso/9780195 170979.001.0001

DeLong, D.W. \& Davenport, T., 2003, 'Better practices for retaining organizational knowledge: Lessons from the leading edge', Employment Relations Today 30(3), 51-63. http://dx.doi.org/10.1002/ert.10098

Desouza, K.C. \& Awazu, Y., 2004, 'Securing knowledge assets: How safe is your knowledge?', viewed 11 November 2010, from http://www.entrepreneur.com/ tradejournals/article/120354108.html

Drucker, P.F., 2001, The essential Drucker, Harper Collins, New York.

Finestone, N. \& Snyman, R., 2005, 'Corporate South Africa: Making multicultural knowledge sharing work', Journal of Knowledge Management 9(3), 128-141. http://dx.doi.org/10.1108/13673270510602827

Frank, D.F., Finnegan, R.P. \& Taylor, C.R., 2004, 'The race for talent: Retaining and engaging workers in the 21st century', Human Resource Planning, September, 12-25.

Habib, A. \& Morrow, S., 2006, 'Research, research productivity and the state in South Africa', Transformation 62, 9-29. http://dx.doi.org/10.1353/trn.2007.0006

Hira, F., 2011, 'Does employee retention affect organizational competence?', Industria Engineering Letters 1(1), 24-39.

Horwitz, F.M., Heng, C.T. \& Quazi, H.A., 2003, 'Finders, keepers? Attracting, motivating and retaining knowledge workers', Human Resource Management Journal 13(4), 23-44. http://dx.doi.org/10.1111/j.1748-8583.2003.tb00103.x

Jeffrey, B., 2011, 'Practitioner guide: how to create a talent management strategy that reflects diversity', viewed 21 November 2011, from http://www.civilservice.gov. uk/wp-content/uploads/2011/09/Talent-Strategies-Practitioner-Guide_tcm6 35853.pdf

Knoco Ltd. n.d., When experts depart: Addressing the risk of knowledge loss, viewed 11 November 2010, from http://www.knoco.com

Lom, M.M., 2012, 'Looming problem of ageing academics threatens top university', University World News, Global edition, 01 July (Issue 228), viewed 11 November 2010 from http://www.universityworldnews.com/article.php?story=20120630122709196

MacGregor, K., 2008, 'South Africa: Challenges of equity, ageing, expansion', University
World News, Global edition, 14 December (Issue 57), viewed 15 November 2011, from $\mathrm{http}: / /$ www.universityworldnews.com/article.php?story=20081214092139847

Madsen, T.L., Mosakowski, E. \& Zahher, S., 2003, 'Knowledge retention and personnel mobility: The non-disruptive effects of inflows experience', Organisation Science 14(2), 173-191. http://dx.doi.org/10.1287/orsc.14.2.173.14997
Malthora Y., 2003, Measuring knowledge assets of a nation: Knowledge systems for development, viewed 21 November 2010, from http://km.brint.com

Martins, E.C., 2010, 'Identifying organisational behavioural factors that influence knowledge retention', DPhil thesis, Dept. Information Science, University of South Africa, viewed 11 November 2011, from http://uir.UNISA.ac.za/bitstream/handle/ $10500 / 4753 /$ pdf

Nelson, K. \& McCann, J.E., 2010, 'Designing for knowledge worker retention and organization performance', Journal of Management and Marketing Research 1, 1-18, viewed 11 November 2010, from http://www.aabri.com/manuscripts/09272.pdf

Notshulwana, V., 2011, 'Expanding opportunity through international equity', Africa Insight 41(2), 142-159.

Ntuli, D., 2007, 'Companies will shell out to retain skills in 2007', Sunday Times: Business Times: Careers, 14 January, p. 1.

Onyancha, O.B., 2010, 'Profiling students using an institutional information portal: a descriptive study of the Bachelor of Arts degree students, University of South a descriptive study of the Bachelor of Arts degree students, University of South Attp://dx.doi.org/10.7553/76-2-78

Oosthuizen, P. \& Nieber, H. 2010. 'The status of talent management in the South African consulting civil engineering industry in 2008: a survey', Journal of the South African Institution of Civil Engineering 52(2), 41-47.

Ramlall, S., 2003, 'Managing employee retention as a strategy for increasing organizational competitiveness', Applied HRM Research 8(2), 63-72.

Smith, L.D., 2007, 'Standard process for knowledge retention', viewed 11 November 2010, from http://www.levidsmith.com/articles/ie591_research_article.pdf

Tettey, W.J., 2006, Staff retention in African universities: Elements of a sustainable strategy, viewed 11 November 2010, from http://siteresources.worldbank.org/ INTAFRREGTOPTEIA/Resources/Academic_Staff_Retention_Final_2_06.pdf

Tettey, W.J., 2010, Challenges of developing and retaining the next generation of academics: Deficits in academic staff capacity at African universities, viewed 11 November 2010, from http://www.foundation-partnership.org/pubs/pdf/tettey deficits.pdf

Thomas, A., 2009, 'Knowledge retention strategies', viewed 11 November 2010, from http://pmtips.net/knowledge-retention-strategies/

University of South Africa (UNISA), 2008, 'Integrated performance management system (IPMS) policy', viewed 11 November 2011, from http://www.unisa.ac.za/cmsys/ staff/contents/departments/hr_policies/docs/IPMS_Council30ct08.pdf

Van der Walt, R., 2010, The contributions of the grey wave to organizations and societies, viewed 11 November 2011, from http://www.workinfo.com/Articles/greywave.htm

Wamundila, S., \& Ngulube, P., 2011, 'Enhancing knowledge retention in higher education: A case of the University of Zambia', South African Journal of Information Management 13(1), 9 pages. http://dx.doi.org/10.4102/sajim.v13i1.439

Wellins, R.S., Smith, A.B. \& Erker, S., 2006, White Paper - Nine best practices for effective talent management, Development Dimensions International, Inc., viewed 5 November 2011, from http://www.ddiworld.com/DDIWorld/media/whitepapers/ ninebestpracticetalentmanagement_wp_ddi.pdf 